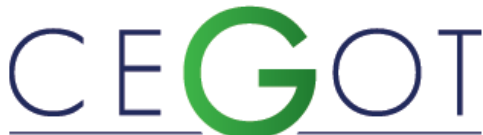

Centro de Estudos de Geografia e Ordenamento do Território
Corte-Real, Madalena

Centro Interdisciplinar de Ciências Sociais (CICS.NOVA), Faculdade de Ciências Sociais e

Humanas - Universidade Nova de Lisboa Avenida de Berna, 26-C, 1069-061 Lisboa, Portugal mcortereal@fcsh.unl.pt

\title{
Keeping afloat - fishing in the Tagus estuary
}

\author{
Mantendo-se à tona de água - a pesca no estuário do Tejo
}

Referência: Corte-Real, Madalena (2017). Keeping afloat - fishing in the Tagus estuary. Revista de Geografia e Ordenamento do Território (GOT), n.o 11 (junho). Centro de Estudos de Geografia e Ordenamento do Território, p. 149-170, dx.doi.org/10.17127/got/2017.11.007

\section{ABSTRACT}

The paper presents the evolution of the Lisbon Metropolitan Area throughout the twentieth and twenty-first century, concerning in particular the municipalities that circumscribe the Tagus estuary and the processes of appropriation and transformation of space, namely of its waterfronts. Under the analysis of urban development, the research addresses groups that immigrated to the area under study and work on local fishing.

Keywords: internal migrations, territory, urban development, local fisheries, Tagus estuary

\section{RESUMO}

O artigo apresenta a evolução da Área Metropolitana de Lisboa ao longo do século XX e XXI, em particular dos municípios que circunscrevem o estuário do Tejo e os processos de apropriação e transformação do espaço, nomeadamente das suas frentes de água. Sob a análise do desenvolvimento urbano, a pesquisa aborda grupos que emigraram para a área em estudo e que trabalham na pesca local.

Palavras-chave: migrações internas, território, desenvolvimento urbano, pesca locais, estuário do Tejo 


\section{Introduction}

This article ${ }^{1}$ aims to reflect the trajectory of fishermen along the territorial development process of the Lisbon Metropolitan Area and how this affected their activity, namely different phenomena that influenced local fishing along the twentieth century and in the present: the internal migration to the area, especially in the first half of the twentieth century; the industrialization process, intensified in the 1960s; the entrance of Portugal in the European Economic Community (1986); and the increase in the number of waterfronts, in particular for recreational purposes. The fishing activity is affected, not only by the local development of the territory but, in an interrelated process and increasingly globalized, by the availability of natural resources and political decisions.

In the evolution of the Portuguese society archaic situations coexist with characteristic elements of modernity and other typical of postmodernity (Ferreira, 2007). The development of the Lisbon Metropolitan Area, intensified with industrialization and an increasing population density, marked by urban sprawl, reflects, throughout the decades, profound transformations revealed in the urban fabric considering morphology, functions as well as social dynamics (Baptista \& Pujadas 2000) but also a persistence that defines a coexistence, or overlapping levels, of various elements reproduced in the landscape like green areas, agriculture, industrial facilities and different housing dynamics.

The present analysis refers to the configuration of different ways of life in a given territory as specific appropriations in space and time, and how they are increasingly compressed by economic, social, cultural and environmental changes in the modes of urban development.

Considering the definition of local fishery, it operates by the coastlines, estuaries, lagoons, rivers near the vessel's dock (INE \& DGRM, 2016). The legislation of the Tagus estuary defines that commercial fishing is limited to the use of vessels with an overall length not

1 This article is based on the updating and deepening of two researches: Master Thesis (Junto à borda d'água: a pesca no estuário do Tejo), ISCTE; and ERIC Project (Effects of river flow changes on the fish communities of the Douro, Tagus and Guadiana estuaries and adjoining coastal areas. Ecological and socio-economic predictions), Oceanographic Institute - Lisbon Faculty of Sciences financed by the Portuguese Foundation for Science and Technology, POCTI Program (ref. PDCTM/P/MAR/15263/1999). 
exceeding $11 \mathrm{~m}$ and engine power up to $65 \mathrm{hp}$ or $48 \mathrm{~kW}$, regardless of the type of deck. The boats are usually handled by two persons; fishermen use a variety of rudimentary methods/gears to catch different species according to the season, and the fisheries are dependent on the tide flow. Official data from the maritime authorities refers that 600 professional fishermen operate in the Tagus estuary.

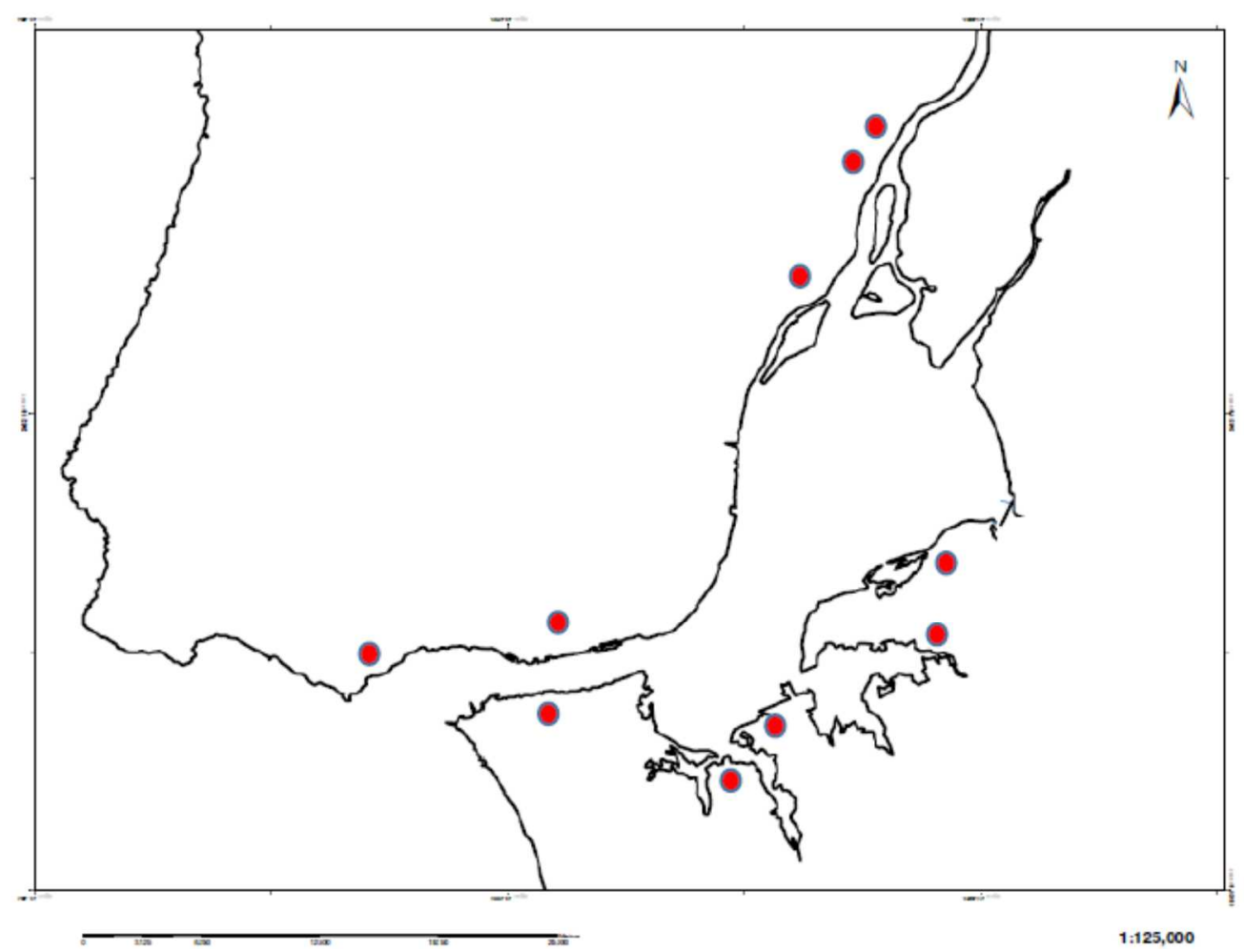

Figure 1 - Map of Tagus estuary - Anchorages of local fishery

This paper is based on more than six years of research concerning local fishing in the Tagus estuary and the analysis relies mainly on field observations and on life stories grounded on in-depth, qualitative interviews to sixteen fishermen in which, following Bertaux (1996), autobiographical narratives are no longer just individual productions but become the reconstruction of the historical and cultural trajectory of particular groups. 


\section{The Tagus Estuary}

The Tagus estuary is the biggest of Western Europe, extending over almost $80 \mathrm{~km}$ and covering an area of about $320 \mathrm{~km}^{2}$. It is located in the Lisbon Metropolitan Area, the most developed and populous part of Portugal with about 1.6 million inhabitants in the eleven surrounding municipalities.

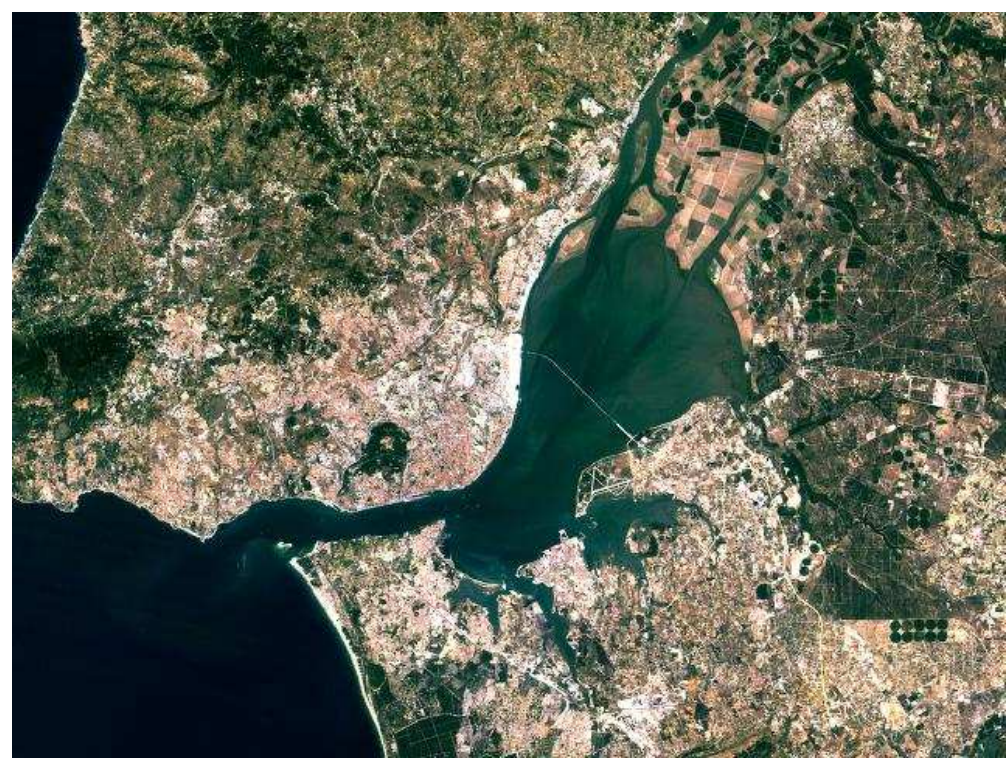

Figure 2 - Map of the Tagus estuary. Source:

http://scrif.igeo.pt/asp/tematica25.asp?CARTA=landsat\&ZOOM=2\&SIZE=3\&x=116055\&y=200239 In economic terms the Tagus estuary, a main entrance to the Iberian Peninsula, has been an important development driver in the region, considering its good navigability, contributing for the transportation of people and goods. The numerous sailing vessels, that filled the landscape in the past, gradually lost its weight, first with the arrival of the railway in the nineteenth century, then with road transportation and the construction of two bridges over the Tagus in 1951 and 1966, however ferries still have a major importance for people that cross the river in their everyday lives. The significance of the aquatic road lead to the appearance of other activities, including the construction and repair of vessels, which also gradually disappeared. Other maritime activities done by coastal communities were fishing, drying cod, the use of tidal power through mills, and salt exploration.

In terms of environmental significance, in 1976 the Natural Reserve of the Tagus estuary was created, which includes a large area of estuarine waters with creeks, marshes, salt flats and alluvial agricultural land. 
It is included, since 1980, in the list of Wetlands of International Importance especially as Waterfowl Habitat (Ramsar Convention). Under the European Union Directive, the Special Protection Area for Wild Birds of the Tagus estuary was also implemented in 1994.

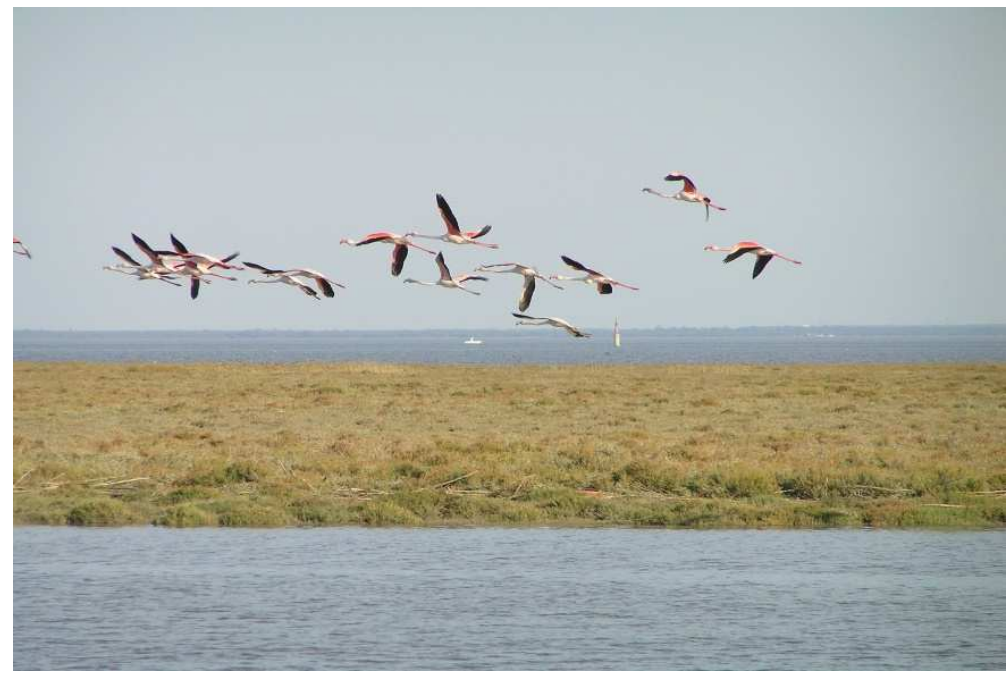

Figure 3 - Natural Reserve of the Tagus estuary

This estuary is characterized by a high fish diversity, namely with commercial value, and is especially important as a nursery area for several species (Costa and Cabral, 1999; Baeta et al., 2005). Considering the ichthyofauna, it is known that estuaries are highly sensitive areas to environmental variations (Cabral et al., 2001). Also, as underlined by Costa et al. (2007), estuaries are among the most productive ecosystems and, at the same time, particularly threatened by conflicting human activities which damage their ecological functions.

The development of the Lisbon Metropolitan Area greatly contributed to environmental degradation. Almeida (1993), referring to the industry in a municipality on the south bank of the estuary, mentions that this eliminated the forms of agricultural life and, by polluting the rich waters of the Tagus, affected fishing communities. Already in the 20 s and 30 s of the twentieth century, as referred by the author, the advance of the industry and its impact are discussed in the local newspapers alluding to gases from the chimneys or to the dumping of waste oils into the river.

Human intervention such as industrial and urban sewage, agriculture (pesticides and fertilizers), port activities (mainly due to the use of TBT on hulls), dams, dredging and fishing (in view of the misuse of improper arts and disregard for the law) (Costa and Elliot, 1991; 
Costa and Cabral, 1999) have been affecting the estuary and its natural resources. The TBT (tributyltin: used in the paintings of vessels to prevent the attachment of living organisms) almost caused the extinction of the oyster (Crassotrea angulata) which was an important export product (Costa, 1999).

In the mid-80s and 90s the decay or transfer of industry responsible for the presence of heavy metals in the estuary, the regeneration of an industrial area, more sewage treatment, have brought significant improvements in environmental terms and, in this context, the reappearance of sensitive species such as the Lusitanian toadfish (Halobatrachus didactylus) (Costa, 1999). Considering the preservation of natural resources, the normalizing function of the administration became increasingly anchored in European regulations (with the entry in the European Economic Community). Costa (1999) stands out however the complexity in imposing these measures in view of the numerous entities involved in the management of the estuary and also the difficulty in attributing responsibility for the state of water.

\section{The Fisheries in Portugal}

Portugal has the 3rd largest Exclusive Economic Zone of the European Union and the 11th in the world $\left(1,727,408 \mathrm{~km}^{2}\right)$. Its narrow continental shelf, that is crucial to the wealth of maritime settlements, is determinant to the type of fishing activities practiced in the country and the specificities of their work organization (Amorim, 2001). Although it is among the countries in the world with the highest fish consumption per capita, since the country joined the European Community, in 1986, fish catch, the number of vessels and fishermen suffered a steep decline. These data, rather than a direct result of entering the EC, represent the evolution of a trend dating back to the 1960s, when fisheries had its peak (Leal, 2006). The oil crises and the prescription of the exclusive economic zone in the following decade, restricting access to fisheries under jurisdiction of other States, affected long distance fishing, in particular cod fishing which is of particular importance. The activity was increasingly confined to the national waters and the consequences were often a turn into local fishing (Amorim, 2001) still present in the south of Europe where, in the case of 
Portugal, it represented, in $2015,39 \%$ of the 17,536 registered professionals (INE and DGRM, 2016).

The common fisheries policy has, as main goals, the conservation of fish stocks; controls external affairs, in order to fish in other countries' waters or in international waters; the structural funds used to help increase the competitiveness of the sector and adapt it to restrictions imposed by the shortage of resources; and a 'common market organization'. In Portugal the fleet has declined, especially in the first decade after the entry in the EC, because of compensatory payments to cease the activity. Besides the cessation (scrapping premiums), the support for the acquisition of new vessels was normally only possible when replacing the old ones (Leal, 2006).

\section{The Metropolitan Area of Lisbon}

The Portuguese economy went through a profound transformation between 1960 and the early 1970s, a period when the country lost its essentially rural character and the industry grew at a strong pace. This process was initialized still in the 1950s, in association with the further opening of the country to the outside in the post-war period focusing primarily on sectors for exportation (Salgueiro, 2001).

In the Lisbon Metropolitan Area, the secondary sector, intensified in the 60s, diverted hand labour from river activities while being the major booster, through numerous manufacturing facilities, and at the same time responsible for the decline of estuarine resources. In the margins of the territory, major concentrated industrial areas attracted thousands of workers.

In the south bank of the Tagus estuary, a striking feature of the urban landscape is that the industrial complex assumes plural forms and different features in space, representing successive stages of its evolution in the Lisbon area, whose definition considered energy use criteria as well as supplying processes or distribution, but also the strategic importance of the magnetism of Lisbon (Cruz, 1973). 
The opening of the first railway line south of the Tagus in 1861, started a major industrial development and, in the late nineteenth century, an important cork centre is defined. Apart from canning and metal mechanics, in the beginning of the twentieth century, major industrial complexes emerged on this side, namely chemical industry. Shipbuilding and, in the $60 \mathrm{~s}$ of the twentieth century, the installation of a steel mill, boosted the economic growth of the country.

In the northern bank, in the last quarter of the nineteenth century, small docks, berths from farms, often raised on wooden stilts and beaches, some of great extension, which also served to the inhabitants' baths, marked the Lisbon's waterfront (Folgado and Custódio, 1999). At this time it also became popular to go bathing at the sea and both sides had beach areas. Only later the coastal area became more widely used as beach spots.

During this period, territories in Lisbon, by the waterfront, were gradually used for industrial development, conquering the river bank and even land from the river (Folgado and Custódio, 1999). Since the beginning of the twentieth century various docks, warehouses, port equipment and maritime stations for passengers settled along the water. With the containerization in the 70s, a new terminal is explored (Salgueiro, 2001). Also several terminals were built, that have been allowing thousands of users to take the ferries to cross between the two shores.

In the 40 s, the northern bank of the estuary, especially the oriental part of Lisbon, also meets a strong industrial expansion in particular with the settlement of a gasometer, the petrochemical sector and the industrial zone of the Port of Lisbon, extending outside the city with the presence of cement, food and chemical industries (Salgueiro, 2001). With the concentration in this area, several problems were meant to be solved, related to the redevelopment of the west zone of the city that was requalified in the context of the Portuguese World Exhibition in 1940, and became an area for public enjoyment, prized for its heritage (Folgado and Custódio, 1999).

Salgueiro (2001) refers that since 1973 the pace of industrial growth became slower and irregular due to the downturn of the international economy, which led to a decrease in the demand for products, which also lost competitiveness against the newly industrialized countries, especially in Southeast Asia, with particular focus on textiles. Furthermore, some 
of the heavy industries of the 60s (steel, heavy engineering, shipbuilding and repair, petrochemical) were strongly affected by economic restructuring linked to the adoption of new technologies, contributing to the crisis that affected the Lisbon region. The dismantling of industries caused a severe crisis especially in the sub region located on the south bank of the estuary. The author underlines that the Lisbon region lost between 30 to 50,000 jobs in the manufacturing, a situation that continued in the 1990s. Some important industrial areas with other types of productions, emerged in the inner parts of the Lisbon Metropolitan Area.

The structure of the Lisbon Metropolitan Area, as it exists today, was formed between the years $60-73$, primarily as a result of a significant migration from rural areas of the country, who travelled to the region in search of better living conditions. According to Ferrão (1996), in spite of the complex accounting, internal migration reached its maximum intensity during the period 69-73. The author emphasizes the irrelevance or disappearance of temporary displacements associated with seasonal rhythms of agricultural life: migration becomes more definitive, directed to cities and into the suburbs and translated into more crosssectoral trajectories. The internal movements are caused by the rural exodus to urban centres that usually implies a change of activity (Lautensach, 1987). In 1981, around $40 \%$ of the population of the Lisbon Metropolitan Area, were not born there (Salgueiro, 2001). Considering the demographic evolution, between the Census of the 1950 and the one of 1980 the population almost doubled reaching 2,5 million. From that point onwards the population will tend to stabilize, with a slight increase in the last two censuses (2001 and 2011). As Ribeiro (1987) refers, the influence of Lisbon penetrates along the lines of communication absorbing, increasingly, small settlements: the industry settles in fertile land, vacation areas, in favour of fast transport where many areas are converted into residential suburbs.

Following the tendencies of Western Europe (Champion, 2001), the attraction of the Metropolitan Area is accompanied by an increasing suburbanization with a strong growth in the metropolitan area and a strong decrease in the city of Lisbon, especially in the $80 \mathrm{~s}$, as can be seen in the following graph. 


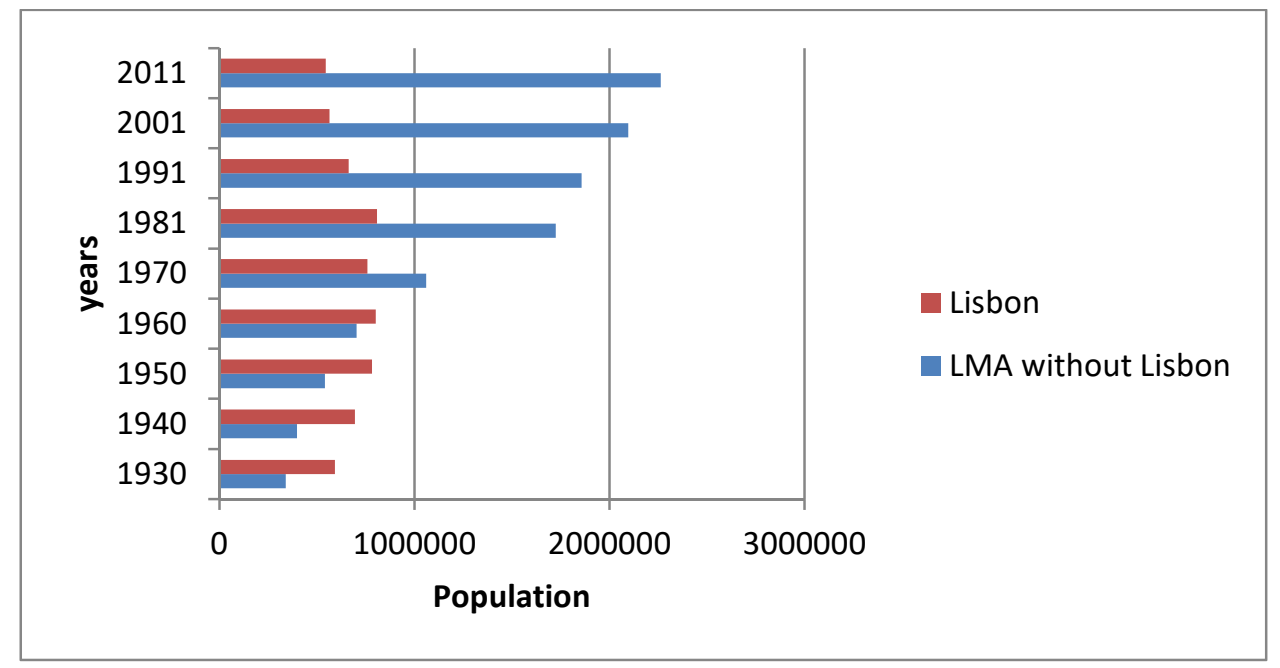

Figure 4 - Evolution of the population in the Lisbon Metropolitan Area (without the municipality of Lisbon) and the municipality of Lisbon between the censuses of 1930 and 2011. Source: Censuses 1930 - 2011 (INE).

The extension of the port facilities, which covers almost the entire waterfront, and whose entity manages around $43 \mathrm{~km}$, covering 11 municipalities of the Tagus estuary, has contributed to its occupation with warehouses, railways, industrial facilities, of which many became derelict areas with the restructuring and reduction of port use in the 1980s. Similarly, there was a sharp decline of the transatlantic movement of passengers although it ranked the highest cruise traffic in the country. In 1998 the port of Lisbon expected to receive 200 stops and more than 120 thousand people (Salgueiro, 2001).

In the 1980s, namely in the context of the entrance of Portugal in the European Economic Community, as Salgueiro (2001) refers, along with an opening of the economy to the outside, the real estate market is boosted and the production system is redefined, with a deconcentration and relocation, a decrease in the employment in the city of Lisbon and gains in the suburban crown. The Metropolitan Area of Lisbon suffers a decline in industrial activity, at least in the traditional sectors of the large base industry and a growth of the high technology industry and services. This period marks the fragmentation of the productive structure, the qualification of the workers, the prominence of the tertiary sector in the capture of employment and more women in the labour market. There are socio-cultural changes, with an increase in schooling, income, consumption, but also social polarization. In this context, a greater mobility with the rise of car acquisition and a strong investment in infrastructures also takes place (Salgueiro, 2001). 
The urban production that prevailed since the 80 s and 90s favours competition based on image promotion and bench marketing, the development of service activities, finance, creative economy and consumption as a way of life of the middle class graduates. The liberal urban planning focuses on core areas of business, redefines abandoned land and structures of industries and port activities for new uses, and favours the creation of large international events (Bourdin, 2010). In this context, in 1998, the Lisbon World Exposition, that took place in the oriental part of the city by the riverfront, included different strategies as stated by official documents: the affirmation of Portugal in the domestic and international framework by demonstrating the ability to implement large scale projects; urban and environmental regeneration of a wide area of about 340 hectares, located by the Tagus, and provide citizens with the right to take advantage of this beautiful riverfront; stimulate the economic activity; under the slogan "The Oceans, a Heritage for the Future", to concur not only to commemorate a historic moment around the Portuguese discoveries but also to increase a greater awareness around its preservation (Parque Expo 98 SA, 1999). This part of the city that was once an industrial, commercial and working-class residence turned thus into a high-end residential, office, leisure and consumption complex (Pereira, 2015).

In order to put cities on the map, local governments seek to turn their urban spaces more attractive. In this context, land-water interface territories, in the post-industrial period, are inseparable from a set of structural transformations that determine their constitution as privileged spaces for the pursuit of urban intervention operations of different natures, like urban regeneration, urban renewal, urban rehabilitation operations) (Fernandes and Sousa, 2016). As referred by Sieber (1993) the revitalization of waterfronts became crucial in a context where retailing, tourism and leisure are central components to their economic programmes. The author, referring to Boston, underlines that people became used to see the water less as an economic resource or job creation but rather as an aesthetic object and as a source of recreation. In this sense, he underlines that the public spaces that are created direct its uses for activities like contemplating, walking, cycling, jogging and picnicking. He also enhances the association around the waterfront redevelopment with an environmental significance of being close to nature and less polluted ambiances. 
In recent years, the Lisbon Metropolitan Area, and in particular the city of Lisbon, are attracting more and more tourists and the revitalization of the waterfront is part of its marketing strategy as an open city. In 2008 the municipality of Lisbon established a protocol in order to strengthen the cooperation with the Port Administration, especially for some areas of the riverfront that currently have no port use.

As can be red in other official documents (CML, 2008) of the surrounding municipalities the goals include the creation of an identity between the city and the river, contributing to the self-esteem of the inhabitants, the preservation of cultural heritage and the promotion of new leisure activities, as well as infrastructures to support tourism, supressing barriers, favouring pedestrian, cycling and public transportation and enabling a visual connectivity.

At the same time on the south bank of the Tagus estuary, three municipalities are promoting, in the international context, the "Lisbon South Bay", looking for investors to requalify three riverside areas that correspond to the old industrial parks, seeking to attract business, housing, commerce and services.

In 2015, considering cruise activity and the existence of three cruise terminals (a new one is being built) the city received more than half a million passengers and 300 calls (Administração do Porto de Lisboa, 2016).

Within this framework it became necessary to think about the transfer of the container terminal. The village on the other side of the river was a possible destination that encountered local resistance, whose actors also want to capitalise the territory for recreation and tourism. The pedestrian area by the riverside was rearranged and a bicycle path takes cyclers to the nearest beaches. The number of restaurants has increased, housing is being renovated including for short-term rentals, events start to take place on a more regular basis. At the edge of the estuary, an informal neighbourhood maintains, at the same time, a vacation, fishing and suburban character. These areas are attracting the interest of creatives in the international context.

Several water sports are developed in the Tagus estuary, which include canoeing, sailing, rowing and fishing. Beaches in the Tagus estuary waters, on the western side after Lisbon, 
are becoming suitable for bathing purposes together with the adjacent coastal areas that are evaluated as having good conditions for bathing.

The number of marinas increased and the passage of the Volvo Ocean Race is one of the greatest achievements in recent years in the nautical tourism, considered to be a great promotion. More sailing schools and small docks emerged as well as a surf spot, downstream of the estuary. All sort of river trips can be made by tourists. Meanwhile there are still some residents who have a different perspective towards the river.

\section{Fishing in the Tagus Estuary}

The development that took place in the twentieth century in the Lisbon Metropolitan Area originated internal migrations, in which the ancestors of the respondents were part of, immigrating to the territory under study attracted either by the river fish supply and the possibility to work in other sectors such as agriculture and industry.

The fishing communities followed different types of production and reproduction practices. For instance, in certain communities with the same background women, also go fishing. The local fishing activity uses a multitude of arts and methods and, apart from the period spent at sea, the fisherman spends a lot of time in the preparation: the nets have to be cleaned, untangled and rolled so as to be ready to be launched to the water. If bait is used, it is still necessary to put it in the numerous hooks and sometimes even catch it, including crab or cocoon. It is a meticulous and completely manual activity that can take several hours. Given the low income, children helped at an early stage in the support of the household.

Two large groups of sea fishermen who immigrated to the Tagus estuary came from the central region of Portugal, creating numerous fishing communities and imposing their cultural identity. One of these groups probably started to settle down around 1830 in places of higher production and easier access to markets in the city of Lisbon and surrounding areas (Soares, 1995). 
It has its first references in the southern borders around the eighteenth century and a text alludes to a battle between them and fishermen from the south (Guevarz, 1750-1800). In the late nineteenth century, Baldaque da Silva, a navy officer and scholar around maritime issues, refers to their presence moving from the centre to the lower part of the Tagus river (Silva, 1891).

The water, in the upper part of Lisbon, strongly marked by agriculture, is not explored by the locals. Santos (1959) in a remarkable ethnographic study in the 1950s, stands out that deep barriers separated seamen from the rural ones.

Coming also from the central region of Portugal, first moving seasonally to the Tagus in the winter, dividing their lives between the river and the sea, particularly for the fishing of shad (Alosa alosa), the nomadic fishermen, known as "sea gypsies", will gradually settle over the first half of the twentieth century, often making their boats home and traveling in their wandering life. The vessels were at the same time place of work and home. Some build barns on stilts and in the late 60s a small neighbourhood was set up by the State along the river to house the families of fishermen for which they participated with work. The formation of nuclei fisheries, clearly delineated in a municipality above Lisbon, may be related to the fact of being a group from the same area with their own cultural identity that remained cohesive.

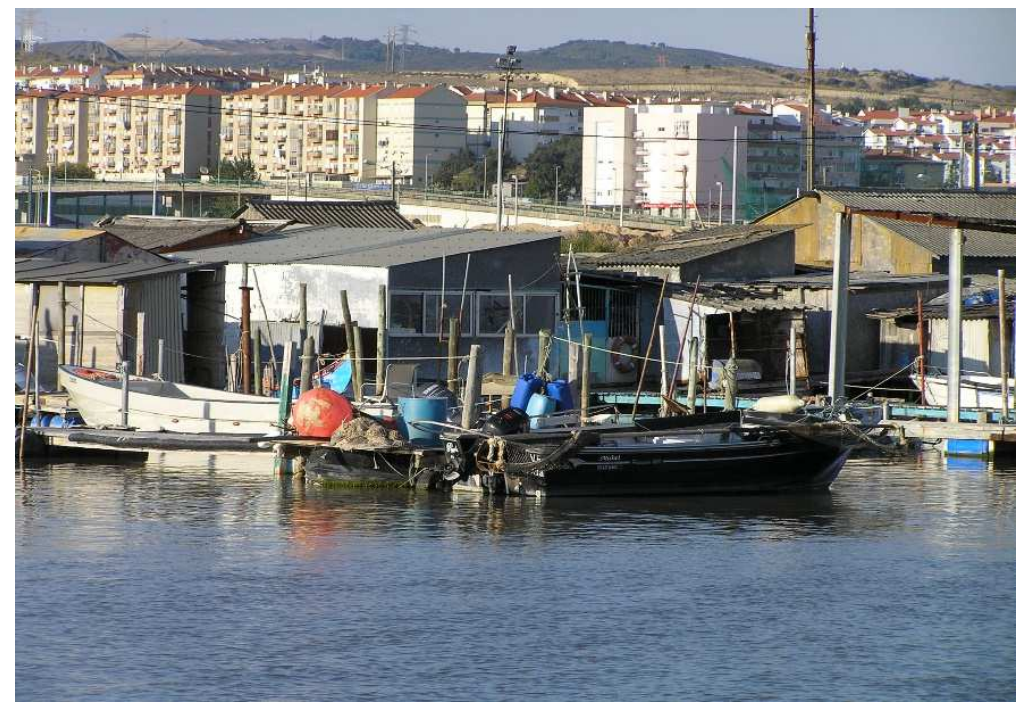

Figure 5 - Fishing community in the Tagus estuary

Initially more upstream in the river, they were forced to move to the estuarine fisheries as shad became scarce, creating local communities. The families, including children, divided 
their activities between fishing and agricultural work like rice weeding or during the summer selling melon, transporting the heavy product to the costumers. Shad, once abundant, began to decline in the 50s. Adelaide dos Santos refers to 10,092 shad caught in 1955 as opposed to 848 fish in 1958 . The reasons for this reduction seem to be the construction of dams that prevent the passage of migrant species that go upstream to spawn and, secondly, to the reduction of the migratory flows due to the opening of a factory in their locality of origin (Santos, 1959).

Considering the inter-sectoral relations that the lower classes were often subject to, the option for this activity seems to be, for most of the respondents, a resource available to anyone who lived near the waterfront. In the interviewed fishermen, there is not always an inherited identity regarding this occupation since it is not necessarily the main work of their ancestor. In most cases, however, it is a legacy left at least by one of the parents or parentsin-law. In the south bank, for instance, an interviewed reported about his father being in the fishing activity and the woman's family working in the canning industry. Fishing activity is marked by a major vulnerability considering that marine resources are affected by aspects like the seasonality of species, climate change, legal requirements, pollution, and dams leading to the need for great adaptability and contributing, in the case of the Tagus estuary, to professionals often combining it with other occupations.

With the development of the industry, multiple activities became related to jobs in the secondary sector and less in agriculture with many respondents reporting to have worked in the factories, often turning to fishing after inheriting the vessel and gears, or doing it as a complementary activity that can be carried out at night. It has also been an important answer to address crisis situations in other jobs. Further occupations, in which the interviewed worked, were reported like working in cargo vessels and long distance fishing. The fall in other fishing activities, particularly in distant waters, made some fishermen turn to local fishing. There is a close proximity between an anchorage in the south bank and the adjacent coastal area. In this municipality, they alternately fish in the sea and river depending on the seasons and especially on the weather.

Currently there are exclusive fishermen and a significant number of those who cross this activity with other occupations or as a complement to the pension. Reasonable levels of 
income are attained by virtue of the profitability of the species in the case of the Tagus estuary, namely seabass, croaker, bream, eel, sole, octopus, cuttlefish and clams. The use of traps registered an increasing demand, mainly because it catches species with commercial value but also because they are less laborious than the nets. For the same reason there is an increasing interest in clam catch.

In this sense, some residents look at the estuary as an economically available resource, namely clams caught with vessels, mainly on the river side opposite to Lisbon, a parish particularly marked by socioeconomic vulnerabilities: in the Census of 2011 it had an unemployment rate of $20 \%$, and the municipality $14 \%$. Here is located the largest fishing community, right by the deep-water terminal, one of the largest in Europe, with a total storage capacity of 200,000 tons for grains and seeds and other agri-food products.

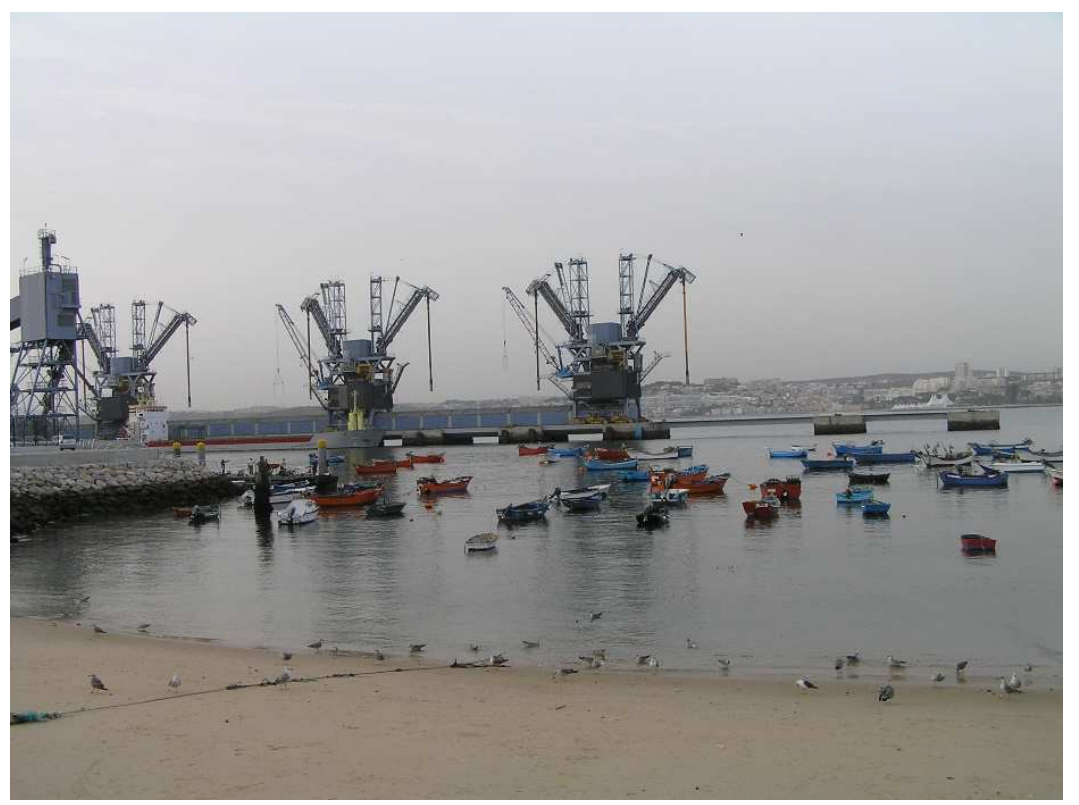

Figure 6 - Fishing community by the storage terminal

Also diving or harvesting is a temptation to catch valuable bivalves, very much appreciated in the gastronomy. Some licenses are given for harvesting but most of the catch is done illegally. Hundreds of people catch clams, including more recently the japonica clam (Ruditapes philippinarum), an exotic species now distributed in the waters of the Tagus estuary (Garaulet, 2011).

Fisheries are more and more dependent on external decisions. In the context of international conservation concerns, fishermen are obliged to follow an increasing number 
of norms, in particular in the framework of the European common fisheries policy (minimum mesh sizes, closed seasons, minimum sizes, restrictions on fishing within certain areas and with certain gears, license for the type of fishing, for arts and for the vessel, more surveillance, security measures and training). The licensing system is an administrative procedure management and limitation of fishing effort which makes sure that the exercise of fishing is subject to prior authorization and annual permit. This prior authorization, in addition to the approval to use certain gears, may allow the practice of specific fisheries targeting certain species (INE and DGPA, 1998).

In the past, given the difficulty of mobility and the need to reduce distances, like the case in rural contexts, fishing required the physical capital to be in the immediate proximity of housing presenting forms of relationship similar to non-urbanized contexts as defined by Rémy and Voyé (1992). In the 60s the beginning of the motorization of vessels minimized the hard work of rowing for hours and the long distances that had to be travelled to sell the fish.

Currently, the territorial development has caused profound changes in the space use of the waterfronts. The fishermen tend to be part of the spatial mobility requirements of everyday life in urban centres and do not necessarily live by the river. The pier where the boat is docked and accoutrements are saved, the sale of fish and place of residence are increasingly defined in different spaces extended through considerable distances.

Although fewer in number, fishing activity is still present, namely on the north of Lisbon. These territories have industrial areas and a strong urban pressure where various locations serve as dormitories namely for those who work in Lisbon, easily accessible by highway and train. Twenty kilometres from Lisbon, a small fishing community is surrounded by an enormous cement plant.

Riversides, once occupied by fishing activity, are being sought for other purposes, mainly leisure. One example is in the north of Lisbon, the dismantling of the fishing neighborhoods (many of the houses only used for storage) to renovate the waterfront and the reconstruction, in a clean reproduction, of the quarter with a museum. 


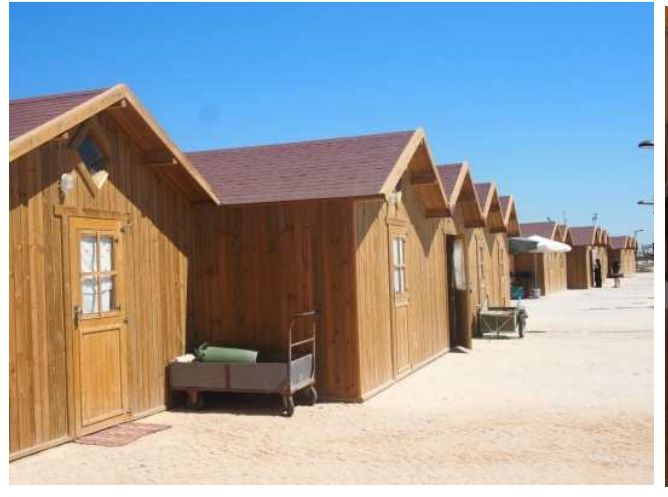

Figure 7 - renewed structures for fishermen

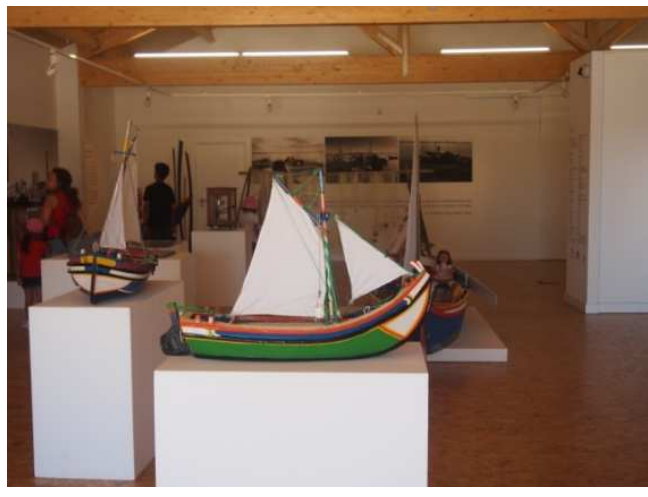

Figure 8 - Fisheries' Museum

Presently, another example is, in Lisbon, the end of the support facilities for fisheries whose area was thought for an international sailing competition, an application that the city did not win, and that is intended to be requalified. Companies running mega-warehouses refrigerators had to leave and the only fish auction of Lisbon closed. There are also restrictions for fishermen to use the beach in the adjacent coastal area of the estuary in the bathing season because of the holidaymakers, another example of the redefinition of use priorities.

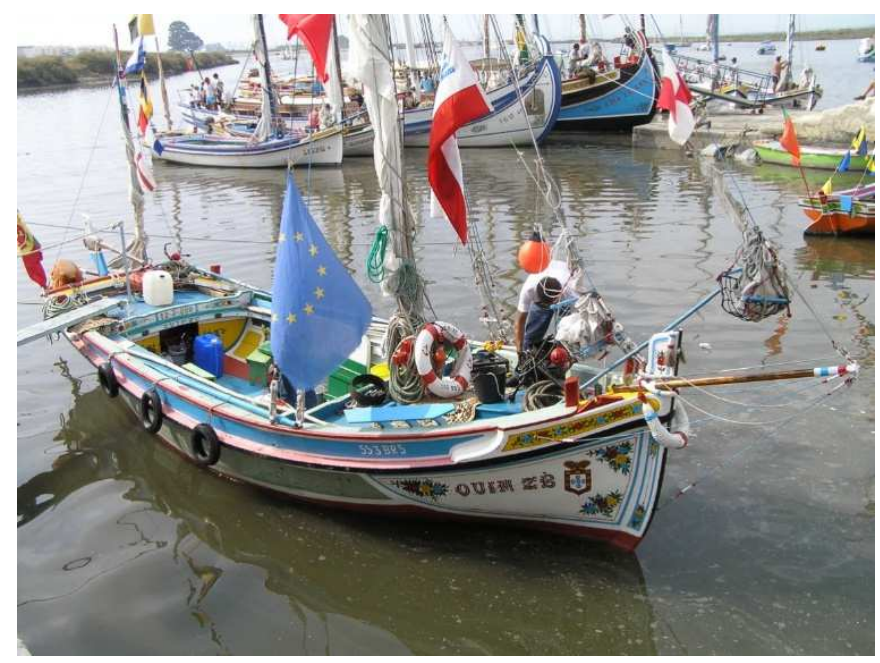

Figure 9 - Local fishing festivities

In terms of valuation of fluvial heritage, some municipalities have been promoting sightseeing in old restored vessels, enabling tourists to enjoy, as stated by an information site, cultural, historical and the natural landscape. Local associations have been supporting heritage protection, including the conservation and repair of traditional vessels. Another example is the safeguarding of what is left of fishing communities above the estuary, with houses on stilts, that is long being discussed. Also in the southern bank, local fishing 
festivities take place: one dedicated to a saint patron of the fishing community still happens on June which includes a fluvial procession with several bedecked traditional fishing vessels. Other activities related to estuary like tide mills and salt pan became also matters of museology. Apart from the environmental potentials of the estuary, like bird watching, the abandoned industrial facilities should increasingly become, in terms of attracting tourism, a strategic local resource in both sides of the riverbanks. Particularly in the south bank, here and there, the riverside has huge abandoned industry facilities, industrial waste, small sheds of more or less professional fishermen, bivalve catchers, often illegal, that can be seen on the low tide, activities that do not belong to the city of consumption and tourism but probably will continue, at least as long as these areas are not requalified, namely no longer being accessible for these practices.

\section{Final Remarks}

Considering the Lisbon Metropolitan Area, the most developed and populated of Portugal, with an important natural landscape, but also a significant material and immaterial heritage, only a closer look at the estuarine waters of the Tagus River reveals the presence of small fishing boats, a residual activity with a minor importance that involves a reduced number of locals dispersed in large urban centers, representing however a niche in terms of activity.

This paper considered the metropolitan development that attracted internal migrations, underwent an important industrialization process and, in the context of globalization had to be redefined with the fall of a significant part of the industrial sector, the upheaval of other specializations and an increasing concern to respond to the needs of the city of consumption and leisure.

Living by the waterside, fishing has been, for some locals, in the face of particular situations of economic vulnerabilities, viewed as one of various possible occupations, combined or alternated with agriculture, industry and even with other fishing activities. 
In view of the lifestyle it imposes, and by being depended of local natural resources, the fishing activity confers features that persist and differ of much of the population of urban areas: it is markedly handcrafted, using rudimentary technology and with a strong dependence and in-depth knowledge regarding the life cycles. In the development of territorial dynamics, throughout the twenty and beginning of the twenty-first century, firstly essentially marked by the secondary sector and port activities, then oriented mainly for leisure, the land along the waterfront has been coveted to purposes other than fishing.

Finally, it is important to consider that these locals engaged in this activity because the fact of living by the water meant a form of subsistence, but also often an attachment to a way a life related with a sense of independence and an attraction for the sea.

\section{References}

ADMINISTRAÇÃO DO PORTO DE LISBOA. Cruise Activity 2015. 2016. Available on WWW: <URL: http://www.portodelisboa.pt/portal/page/portal/PORTAL_PORTO_LISBOA_ING/CRUZEIROS/STATISTICS/Cruise \%20Activity_2.pdf>.

ALMEIDA, A. N. de. A fábrica e a família: famílias operárias no Barreiro. Barreiro: Câmara Municipal, 1993. ISBN: 972-95121-9-1.

AMORIM, I. Trabalho e ocupações no sector das pescas: esboço de conhecimentos e proposta para um sistema de classificação e de investigação histórica. In Madureira N. L. (coordenador); Amorim, I. (organizadora). História do Trabalho e das Ocupações. Vol. Il - As pescas. Oeiras: Celta Editora, 2001, pp. 5-24. ISBN: 972-774127-4.

BAETA, F.; PINHEIRO, A.; CORTE-REAL, M.; COSTA, J. L.; ALMEIDA, P. R. de; CABRAL, H. and COSTA, Maria José. Are the fisheries in the Tagus estuary sustainable? Fisheries Research. 2005, 76(2), 243-251.

DOI 10.1016/j.fishres.2005.06.012.

BAPTISTA, L. V.; PUJADAS, J. J. Confronto e entreposição: os efeitos da metropolização nas vidas das cidades. Fórum Sociológico 2000, 3/4(2a Serie), 293-308.

BERTAUX, D. Les récits de vie: perspective ethnosociologique. Paris: Éditions Nathan, 1996. ISBN-13: 9782091904467

BOURDIN, A. L'urbanisme après la crise. Paris: Éditions de l'Aube, 2010. ISBN: 978-2815900232.

CABRAL H. N.; COSTA M. J.; SALGADO J. P. Does the Tagus estuary fish community reflect environmental changes? Climate Research. 2001, 18, 119-126.

CÂMARA MUNICIPAL DE LISBOA (CML). Plano Geral de Intervenções da Frente Ribeirinha de Lisboa. Documento de Enquadramento. Lisboa: Câmara Municipal de Lisboa - Direcção Municipal de Planeamento Urbano Departamento de Planeamento Urbano, 2008.

CHAMPION, T. Urbanization, Suburbanization, Counterurbanization and Reurbanization. In PADISON, R. (ed.) Handbook of Urban Studies. London: SAGE Publications, 2001, pp. 143-161. DOI 10.4135/9781848608375.n9. 
COSTA, M. J.; VASCONCELOS, R.; COSTA, J. L.; CABRAL, H. N. River flow influence on the fish community of the Tagus estuary (Portugal). Hydrobiologia. 2007, 587(1), 113-123. DOI 10.1007/s10750-007-0690-x.

COSTA, M. J. O Estuário do Tejo. Lisboa: Edições Cotovia, 1999. ISBN: 972-8423-39-X.

COSTA, M. J.; CABRAL H. Changes in the Tagus nursery function for commercial fish species: perspectives for management. Aquat Ecol. 1999. Vol. 33(3), 287-292. DOI: 10.1023/A:1009904621771.

COSTA, M. J.; ELLIOT, M. Fish usage feeding in two industrialized estuaries. The Tagus, Portugal, and the Forth, Scotland. In ELIOT, M; DUCROTOY JP (Eds.) Estuaries and coasts: spatial and temporal inter-comparisons. Fredensborg: Olsen \& Olsen, 1991, pp. 289-297. ISBN 87-85215-17-1.

CRUZ, M. A. A margem sul do estuário do Tejo: factores e formas de organização do espaço. 1ed. Montijo: Gazeta do Sul, 1973.

FERNANDES, A.; SOUSA, J. A definição de frente ribeirinha: subsídios para uma delimitação conceptual e espacial. Revista de Geografia e Ordenamento do Território (GOT), 10 2016, 113-131. dx.doi.org/10.17127/got/2016.10.006.

FERRÃO, J. Três Décadas de consolidação do Portugal demográfico. In BARRETO, A. (Org.). A Situação Social em Portugal, 1960-1995. Lisboa: ICS., 1996, pp. 165-190. ISBN: 972-671-043-X.

FERREIRA, A. F. Gestão Estratégica de Cidades e Regiões. Lisboa: Fundação Calouste Gulbenkian, 2007. ISBN: 978-972-31-1133-0.

FOLGADO D.; CUSTÓDIO J. Guia do Património Industrial. Lisboa: Livros Horizonte, 1999. ISBN: 9789722410564.

GARAULET, L. L. Estabelecimento do bivalve exótico Ruditapes philippinarum (Adams \& Reeve, 1850) no estuário do Tejo: caracterização da população actual e análise comparativa com a congénere nativa Ruditapes decussatus (Linnaeus, 1758) e macrofauna bentónica acompanhante. Dissertação para obtenção do grau de Mestre em Ecologia Humana, pela Faculdade de Ciências da Universidade de Lisboa, 2011.

GUEVARZ, F. Nova relação da batalha naval, que tiveram os algarvios com os saveiros nos mares, que confinão com o celebrado paiz da Trafaria. Catalumna: en la imprenta de Francisco Guevarz, 1750-1800.

INSTITUTO NACIONAL DE ESTATÍSTICA (INE). DIREÇÃO-GERAL DE RECURSOS NATURAIS, SEGURANÇA E SERVIÇOS MARÍTIMOS (DGRM). Estatísticas da Pesca 2015. Lisboa: Instituto Nacional de Estatística, 2016.

INSTITUTO NACIONAL DE ESTATÍSTICA (INE). Resultados definitivos dos recenseamentos de 1930, 1940, 1950, 1960, 1970, 1981, 1991, 2001 e 2011.

INSTITUTO NACIONAL DE ESTATíSTICA (INE); DIRECÇÃO-GERAL DAS PESCAS E AQUICULTURA (DGPA). Pescas em Portugal = Portuguese Fisheries. Lisboa: Instituto Nacional de Estatística, 1998.

LAUTENSACH, H. Geografia da População. In RIBEIRO, O., LAUTENSACH, H. e DAVEAU, S. (Eds.). Geografia de Portugal III, O Povo Português. Lisboa: Edições João Sá da Costa, 1989, pp. 705-729. ISBN: 972-9230-31-5.

LEAL, M. Sector das Pescas - Balanço de 20 anos de adesão à Comunidade Europeia. Lisboa: IFADAP, 2006.

PARQUE EXPO 98 SA. 1998 Lisbon World Exposition - report, 1999.

PEREIRA, P. Production of public space and everyday life in a gentrified area of Lisbon. The Portuguese Journal of Social Science. Vol. 14(2). 2015. Available on WWW: <URL: http://pjss.iscte.pt/index.php/pjss/article/view/195>.

RÉMY, J.; VOYÉ, L. La ville: vers une nouvelle définition? Collection: Villes et Entreprises. Paris: L'Harmattan, 1992. ISBN: 2-7384-0956-3.

RIBEIRO, O. Evolução e Distribuição da População. In RIBEIRO, O., LAUTENSACH, H. e DAVEAU, S. (Eds.). Geografia de Portugal III, O Povo Português. Lisboa: Edições João Sá da Costa, 1989, pp. 731-778. ISBN: 9729230-31-5

SAlgUeIRO, T. B. Lisboa, Periferia e Centralidades. Oeiras: Celta, 2001. ISBN: 972-774-109-6. 
SANTOS, M. A. N. Os avieiros: estudo de geografia humana. Estudo Geográfico. Tese de Licenciatura. Lisboa: Faculdade de Letras da Universidade de Lisboa, 1959.

SIEBER, T. R. Public Access on the Urban Waterfront: A Question of Vision. In ROTTENBERG R. and MCDONOGH, G. (Eds.). The Cultural Meaning of Urban Space Westport, Connecticut London: Bergin \& Garey, 1993, pp. 173- 193. ISBN 978-0-89789-320-6.

SILVA, A. A. B. da. Estado actual das pescas em Portugal. Lisboa: Imprensa Nacional, 1891.

SOARES M. Varinos e Avieiros. In MAGALHÃES, F. (Eds.). Navegando no Tejo, Lisboa: Comissão de Coordenação da Região de Lisboa e Vale do Tejo, 1995, pp. 77-84. 